\title{
Heterogeneity of PD-L1 Expression and Relationship with Biology of NSCLC
}

\author{
MARIA BASSANELLI ${ }^{1,2}$, STEFANO SIOLETIC ${ }^{3}$, MAURIZIO MARTINI ${ }^{4}$, SILVANA GIACINTI ${ }^{5}$, \\ ANTONELLA VITERBO ${ }^{6}$, ANITA STADDON ${ }^{7}$, FABRIZIO LIBERATI $^{3}$ and ANNA CERIBELLI ${ }^{1}$ \\ Departments of ${ }^{1}$ Oncology, and ${ }^{3}$ Anatomic Pathology and Histology, San Camillo De Lellis Hospital, Rieti, Italy; \\ Departments of ${ }^{2}$ Medical and Surgical Sciences and Translational Medicine - \\ Ph.D. Programme in Experimental and Clinical Research Methodology in Oncology, \\ and ${ }^{5}$ Clinical and Molecular Medicine, Sapienza University of Rome, Rome, Italy; \\ ${ }^{4}$ Division of Anatomic Pathology and Histology, Agostino Gemelli School of Medicine, \\ Catholic University of the Sacred Heart, Rome, Italy; \\ ${ }^{6}$ Department of Oncology; Misericordia Hospital, Grosseto, Italy; \\ ${ }^{7}$ Department of Medical Oncolgy, Tallaght University Hospital, Dublin, Ireland
}

\begin{abstract}
Immunotherapy with monoclonal antibodies against programmed cell death (PD-1), such as nivolumab and pembrolizumab, has significantly improved the survival of patients with metastatic non-small cell lung cancer (NSCLC). In order to determine the subset of patients that can benefit most from these therapies, biomarkers such as programmed death ligand-1 (PD-L1) have been proposed. However, the predictive and prognostic role of the use of PD-L1 is controversial. Anti-PD-L1 immunohistochemistry may not represent the actual status of the tumour because of individual variability and tumour heterogeneity. Additionally, there may be analytical variability due to the use of different assays and antibodies to detect PD-L1. Moreover PD-L1 expression is also regulated by oncogenic drivers in NSCLC, such as epidermal growth factor receptor (EGFR), echinoderm microtubule-associated protein-like 4 (EML4) fusion with anaplastic lymphoma kinase (ALK), and Kirsten rat sarcoma viral oncogene homolog (KRAS). Preclinical studies have shown the potential role of targeted therapy in immune escape mechanisms in NSCLC cells. This review summarizes current literature data on the heterogeneity of
\end{abstract}

This article is freely accessible online.

Correspondence to: Antonella Viterbo, via Senese 169, 58100 Grosseto, Italy. E-mail: antonella.viterbo@gmail.com

Key Words: Programmed death ligand-1 (PD-L1) expression, programmed cell death (PD-1), lung cancer, immunotherapies, NSCLC, review.
PD-L1 expression and the relationship with such factors and with clinicopathological features of NSCLC.

Lung cancer is the second most common tumour in both men and women, while it is by far the leading cause of cancer-related deaths in both genders in Europe. This tumour is classified into two major clinicopathological groups: small cell lung carcinoma and non-small cell lung carcinoma (NSCLC). Approximately $80 \%$ of lung cancers are NSCLC and more than $70 \%$ of patients with NSCLC are diagnosed with locally advanced or metastatic disease. Although platinum-based combination chemotherapies have been the first-line standard treatment for many years, molecular advances have brought new therapy options, such as epidermal growth factor receptor (EGFR) tyrosine kinase inhibitors (TKIs) and anaplastic lymphoma kinase (ALK)directed therapies for specific subset of patients with tumours that carry specific alterations ( $E G F R$ mutations or $A L K$ translocations). Despite all the progress in drug development, the 5-year survival rate of patients at all stages is still considered relatively low (17.4\%) (1). Therefore, there is great interest in new treatment strategies. Thus, immunotherapy is considered a new and very promising therapeutic option. Some of these new therapies are based on monoclonal antibodies that are designed to target immune-checkpoint molecules such as programmed cell death protein 1 (PD-1) or its ligand (PD-L1).

PD-1, a member of the CD28 family, is a key immunecheckpoint receptor expressed on the surface of activated T-, $\mathrm{B}-$, and natural killer (NK) cells and plays a crucial role in tumour immunoescape. Its ligand PD-L1 is up-regulated in different types of tumours and binds PD-1 to reduce immunoresponses. PD-L1 is expressed in $19.6 \%$ to $65.3 \%$ of 
cases of NSCLC and positivity rates range from $13 \%$ to $70 \%$ $(2,3)$. The expression of PD-L1 assessed by immunohistochemistry (IHC) has been correlated with response and overall survival of patient treated with immune-checkpoint inhibitor therapies in NSCLC, such as nivolumab and pembrolizumab, two antibodies targeting PD-1 (4-7). However, its significance remains unclear and controversial (8). IHC using antibody to PD-L1 may not represent the true status of the tumour because of heterogeneity of expression $(9,10)$ due to various factors, such as stage of disease, prior chemotherapy $(11,12)$ or targeted therapy (13), prior radiotherapy $(14,15)$, gender, associated concomitant medications e.g. steroids, viral infection $(16,17)$, mutation status of NSCLC, tumour differentiation, histology, the presence of $\mathrm{CD}^{+}$tumour-infiltrating lymphocytes (TILs) (18-21), differences in diagnostic sample type (e.g. cytology, large tumour tissue, small biopsy sample) and different assay methods $(22,24)$ used to detect PD-L1 level, subsequently with inter-assay variability or discordance (25-31) (Table I).

\section{PD-L1 Expression and Prognostic Value in Lung Cancer}

Pan et al. showed the association between high PD-L1 expression in NSCLC and poor tumour differentiation [well/moderately $v s$. poorly differentiated, odds ratio $(\mathrm{OR})=0.53,95 \%$ confidence interval $(\mathrm{CI})=0.39-0.72, p<0.0001]$. This metaanalysis concluded PD-L1 expression to be a poor prognostic factor for overall survival (OS) [positive $v s$. negative PD-L1 expression, hazard ratio $(\mathrm{HR})=1.47,95 \%$ confidence interval $(\mathrm{CI})=1.19-1.83, p=0.0004]$ (32). Mu et al. studied the association of expression level of PD-L1 in lung cancer with histology and OS. The rate of expression of PD-L1 in adenocarcinoma was higher than in the squamous cell variant $(65.2 \%$ vs. $44.4 \%$, $p=0.032$ ) and PD-L1-positive NSCLC cells were associated with a poor prognosis. Patients with survival time after surgery of less than 3 years had a higher PD-L1 expression rate $(p=0.034)$ (33).

The analysis of four pivotal adjuvant chemotherapy trials (IALT, ANITA, JBR.10 and CALGB 9633) conducted by the LACE-Bio (Lung adjuvant Cisplatin Evaluation Biomarker) collaborative group showed that PD-L1 IHC is neither a prognostic factor nor a predictor of survival benefit from adjuvant chemotherapy in early-stage completely resected NSCLC (34). Whole-exome sequencing analysis of earlystage lung adenocarcinoma revealed that PD-L1 was the most elevated immune marker in smokers $(p=0.006)$ and that PD-L1 expression level was positively correlated with somatic mutation burden (35).

Sheng et al. described the impact of neoadjuvant chemotherapy on PD-L1 expression of tumour cells and tumour-infiltrating immune cells (36). The rate of positive PDL1 expression changed from $75 \%$ to $37.5 \%$ after neaoadjuvant treatment $(p=0.003)$. A subgroup analysis showed that patients receiving TKIs (erlotinib, gefitinib or icotinib) $(p=0.004)$ or taxane-based chemotherapy ( $p=0.006)$ tended to exhibit PD-L1 reduction, but those who received pemetrexed-based regimens did not. Patients who responded to chemotherapy presented reduced PD-L1 levels in tumour cells $(p=0.004)$. The switch from negative to positive PD-L1 status was associated with inferior disease-free survival (DFS) when compared with the contrary change (median DFS=9.6 vs. 25.9 months, $p=0.005$ ).

McGranahan et al. showed that a higher somatic mutation burden was associated with improved objective response rate $(\mathrm{ORR}=63 \%$ vs. $0 \%, p=0.03)$, durable clinical benefit $(p=0.02)$ and progression-free survival $(\mathrm{PFS}=14.5$ vs. 3.7 months, $p=0.01, \mathrm{HR}=0.19,95 \% \mathrm{CI}=0.05-0.70)$ in patients with NSCLC treated with pembrolizumab. Molecular signature of smoking due to tobacco carcinogen-related mutagenesis $(\mathrm{ORR}=56 \% \mathrm{vs}$. $17 \%, p=0.03$; durable clinical benefit $=77 \%$ vs. $22 \%, p=0.004$; median PFS not reached vs. 3.5 months; $p=0.0001$ ), higher neoantigen burden (median $\mathrm{PFS}=14.5$ vs. 3.5 months, $p=0.002$ ) and DNA-repair pathway mutations [polymerase delta 1 $(P O L D 1)$, polymerase $\varepsilon$ (POLE), DNA mismatch-repair protein (MSH2), protein kinase DNA-activated catalytic polypeptide $(P R K D C)$, and cell-cycle checkpoint protein $R A D 17)$ were associated with higher efficacy and mutation burden (37).

McGranahan et al. showed correlation between a high neoantigen burden and longer OS in lung adenocarcinoma $(p=0.025)$. In early-stage NSCLC, the neoantigens were associated with an inflamed tumour microenvironment enriched with activated $\mathrm{CD} 8^{+} \mathrm{T}$-cells, subsequently expressing high levels of PD-L1. Advanced NSCLCs treated with pembrolizumab with a high clonal neoantigen burden and low neoantigen intra-tumoural heterogeneity were associated with a higher PD-L1 expression, resulting in a longer PFS (38). Okita et al. found that PD-L1 overexpression was associated with male sex $(p=0.004)$, smoking history $(p=0.002)$, higher maximum standardized uptake value (SUVmax) on positronemission tomography $(p<0.001)$, squamous cell carcinoma histology $(p=0.003)$, higher histological grade $(p=0.003)$, node metastasis-positive status $(p=0.015)$ and advanced pathological stage in resected NSCLC $(p=0.014)$ (Table I) (45).

\section{PD-L1 Expression and Oncogenic Drivers}

Several studies showed that PD-L1 expression is also regulated by oncogenic drivers in NSCLC, such as EGFR, echinoderm microtubule-associated protein like 4 (EML4$A L K)$, proto-oncogene tyrosine-protein kinase ROS (ROS1), KRAS, tumour protein p53 (TP53), mesenchymal-toepithelial transition (MET) and phoasphatidylinositol-4,5 bisphosphate 2-kinase catalytic subunit alpha (PIK3CA) (39).

\section{EGFR Pathway}

Several studies showed that EGFR pathway activation was associated with higher PD-L1 expression (40-43). It has been 
Table I. Clinicopathological features associated with high expression of programmed death ligand-1 according to literature review.

\begin{tabular}{|c|c|c|}
\hline Author, year (ref) & $\begin{array}{l}\text { Clinicopathological } \\
\text { features studied }\end{array}$ & Satus \\
\hline Tang et al., 2015 (46); Chen et al., 2015 (43); D'Incecco et al., 2015 (41) & EGFR status & EGFR mutation \\
\hline Chen et al., 2015 (43) & $E G F R-\mathrm{T} 790 \mathrm{M}$ mutation & EGFR-T790M mutation positive \\
\hline Ota et al., 2015 (56) & $E M L 4-A L K$ status & EML4-ALK fusion protein \\
\hline Han et al., 2016 (30) & Priortherapy & EGFR-TKIs \\
\hline Hong et al., 2016 (55) & ALK-TKIs & Crizotinib sensitive or resistant \\
\hline Chen et al., 2015 (43); D'Incecco et al., 2015 (41) & KRAS status & KRAS mutation \\
\hline D'Incecco et al., 2015 (41); Tang et al., 2015 (46); Ota et al., 2015 (56) & Histology & Adenocarcinoma \\
\hline Okita et al., 2017 (45) & Histology & Squamous cell carcinoma \\
\hline D'Incecco et al., 2015 (41); Ota et al., 2015 (56) & Gender & Female \\
\hline Okita et al., 2017 (45) & Gender & Male \\
\hline Rizvi et al., 2015 (37); McGranahan et al., 2016 (38); Kadara et al., 2017 (61) & Somatic mutation burden & High \\
\hline Gainor et al., 2016 (47) & CD8+ TILs & High \\
\hline Okita et al., 2017 (45); Kadara et al., 2017 (61) & Smoking status & Yes \\
\hline
\end{tabular}

EGFR: Epidermal growth factor receptor; EML4-ALK: echinoderm microtubule-associated protein-like 4 gene fusion with anaplastic lymphoma kinase gene; TILS: tumour-infiltrating lymphocytes.

shown that EGFR-mutant NSCLC cell lines compared to $E G F R$ wild-type (WT) cell lines have a significantly higher protein expression of PD-L1. EGFR activated by EGF stimulation, exon-19 deletion and L858R mutation induced PD-L1 expression, suggesting that constitutive oncogene pathway activation can up-regulate PD-L1. EGFR activation up-regulated PD-L1 through p-ERK1/2/p-c-JUN, which are involved in proliferation, anti-apoptosis and invasion of tumour cells. Inhibition of EGFR by EGFR TKIs can reduce D-L1 levels and can reverse the suppression of T-cells by enhancing the production of interferon- $\gamma$ in EGFR-TKIsensitive NSCLC. The expression of PD-L1 was highest in EGFR-TKI-resistant cells (EGFR -T790M mutation).

Zhang et al. demonstrated that activated EGFR upregulated the expression of PD-L1 through the interleukin 6 (IL6)/Janus kinase (JAK)/signal transducer and activator of transcription 3 (STAT3) signalling pathway in NSCLC cells (44). EGFR-TKIs treatment reduced the secretion of IL6 from cancer cells and then reduced the activation of JAK/STAT3, thus inhibiting the expression of PD-L1, leading to reduced proliferation and increased apoptosis of NSCLC cells. Okita et al. evaluated the impact of PD-L1 expression and EGFR and human epidermal growth factor receptor 2 (HER2) in tumour cells from pathological stages IA-IIIA NSCLC (45). They showed that PD-L1 overexpression was associated with poor recurrence-free survival $(p=0.012)$ and OS $(p<0.001)$. It was also positively correlated with EGFR expression $(p=0.027)$ and inversely correlated with HER 2 expression $(p<0.001)$ in resected NSCLC tissue. Moreover, they suggested that PD-L1 expression might be partially regulated via phosphatidyli-nositol-3-kinase/protein kinase B (PI3K/AKT) and JAK/STAT pathways.
Tang et al. found that high levels of PD-L1 in patients with EGFR-WT were a prognostic factor of poor OS $(p=0.029)$. In EGFR-WT NSCLC, cancer cells can evade host immune responses by expressing PD-L1 to downregulate cytotoxic T-lymphocyte activation in the tumour microenvironment, allowing cancer cells to survive (46). Gainor et al. showed the lack of concurrent PD-L1 expression with high levels of $\mathrm{CD}^{+}$TILs in EGFR-mutant patients, suggesting an innate resistance to the activity of PD-1/PD-L1 inhibitors (47).

Akbay et al. demonstrated that activation of the EGFR pathway induced PD-L1 expression and led to evasion of the host antitumour immune response (43). EGFR-driven tumours may induce an immunosuppressive microenvironment in the lung with an increase of immunosuppressive cytokines, growth factors and chemokines involved in immune cell accumulation. EGFR inhibitors reduced the PD-L1 level in NSCLC cell lines with activated EGFR, confirming the correlation between PDL1 expression and EGFR signalling (43).

D'Incecco et al. found that PD-L1-positive patients treated with EGFR-TKIs (gefitinib or erlotinib) had higher response rates $(61.2 \%$ vs. $34.8 \%, p=0.01)$ and longer time to progression (11.7 months vs. 5.7 months, $p<0.0001$ ), compared to PDL-1 negative individuals. In a subgroup of patients with EGFRmutated NSCLC, time to progression was significantly longer (29.5 months vs. 21.1 months, $p=0.01$ ) in PD-L1-positive than in PD-L1-negative cases (48). Haratani et al. showed that patients without EGFR-T790M mutation but with other EGFR mutations are more likely to benefit from nivolumab after EGFR-TKI treatment (PFS=2.1 vs. 1.3 months, $p=0.099$ ), possibly as a result of higher PD-L1 expression than in EGFRT790M-positive patients (49) (Table II). 
Table II. Relationship between expression of programmed death ligand-1 (PD-L1l and epidermal growth factor receptor (EGFR)-tyrosine kinase inhibitors (TKIs).

\begin{tabular}{|c|c|c|c|c|}
\hline Author, year (ref) & Parameter & PD-L1 status & Outcome & $p$-Value \\
\hline D’Incecco et al, 2015 (41) & EGFR-TKIs & High $v s$. low & $\begin{array}{c}\text { Better RR (61.2\% vs. } 34.8 \% \\
\text { Longer TTP (11.7 vs. } 5.7 \text { months) }\end{array}$ & $\begin{array}{c}0.01 \\
<0.0001\end{array}$ \\
\hline D’Incecco et al., 2015 (41) & EGFR-TKIs ( $E G F R$ mutation NSCLC) & High $v s$. low & Longer TTP (29.5 vs. 21.1 months & 0.01 \\
\hline Haratani et al., 2017 (49) & $\begin{array}{c}\text { Nivolumab after PD during EGFR-TKIs } \\
\text { (EGFR-T790M-negative } v s . \\
E G F R \text {-T790M-positive })\end{array}$ & High & Longer PFS (2.1 vs. 1.3 months) & 0.099 \\
\hline
\end{tabular}

H: High; L: low; PD: progressive disease; PFS:progression-free survival; TTP: time to progression, RR: response rate.

In the CheckMate 057 trial, a subgroup analysis showed that nivolumab did not confer a survival benefit in patients with non-squamous EGFR-mutated tumours when compared with docetaxel therapy $(\mathrm{HR}=1.08,95 \% \mathrm{CI}=0.69-2.00)(6)$. Similar results emerged from KEYNOTE 010 trial: no significant survival advantage was shown in EGFR-mutant NSCLC $\quad(\mathrm{HR}=0.88,95 \% \mathrm{CI}=0.45-1.70)$ treated with pembrolizumab when compared with $E G F R$-WT $(\mathrm{HR}=0.66$, $95 \% \mathrm{CI}=0.55-0.80)(50)$.

\section{EGFR TKIs in Combination with Immunotherapy}

Based on pre-clinical data that activation of the oncogenic EGFR pathway up-regulates PD-L1 expression, enhancing susceptibility of NSCLC cells to PD-L1 blockade, combining EGFR-TKIs with immunotherapy appears to be a promising therapeutic approach (43). Combination therapy of different EGFR-TKIs with various immune-checkpoint inhibitors is currently under investigation (51). Preliminary results from ongoing phase I/II clinical studies of combination therapies show promising efficacy but high incidence of severe adverse events: nivolumab plus erlotinib (NCT02574078) (52) was associated with $19 \%$ of grade 3 toxicities; erlotinib plus atezolizumab (NCT02013219) recorded 39\% grade 3/4 adverse events, such as liver enzyme elevation (7\%), pyrexia (7\%) and rash (7\%); the combination of osimertinib plus durvalumab (NCT02143466) (53) was associated with $38 \%$ of grade 3/4 interstitial lung disease; and grade 3/4 liver enzyme elevation was reported with the association of gefinitib plus durvalumab (NCT02088112).

\section{EML4-ALK Fusion Gene}

$A L K$ rearrangement appears to be associated with higher PDL1 expression (54-59). Hong et al. found that overexpression of ALK fusion protein increased PD-L1 expression through pERK $1 / 2$ and p-AKT signalling but not p-JAK3/STAT 3 signalling in NSCLC cells (55). Therefore, EML4-ALK fusion protein represents intrinsic regulation of PD-L1 in
NSCLC with $E M L 4-A L K$ gene fusion. They demonstrated that up-regulation of PD-L1 by EML4-ALK fusion protein induced the apoptosis of T-cells through the PD-L1-PD-1 axis. Inhibiting ALK by sensitive TKIs can reverse the suppression of T-cells and reduce PD-L1 expression. Inferferon- $\gamma$ was increased in a co-culture of EML4-ALK-positive cells and Tcells after treatment with ALK-TKI crizotinib or LDK378, especially LDK378. They found that PD-1 antibodies were effective in both crizotinib-sensitive and resistant NSCLC cells. No synergistic effect of combining ALK-TKIs and antibodies to PD1 and PD-L1 was observed.

Ota et al. showed that PD-L1 expression was higher in NSCLC cells positive for EMLA-ALK rearrangement than in those which were wild-type $(p<0.001)(56)$. ALK tyrosine kinase activity induced by alectinib, a selective inhibitor of ALK, increased the expression of PD-L1 in cells positive for EML4-ALK rearrangement. They found that PD-L1 expression was up-regulated via MEK/ERK and PI3K/AKT signalling in EMLA-ALK fusion-positive NSCLC cells, revealing a direct relationship between oncogenic drivers and PD-L1 expression.

\section{KRAS Status}

In a recent meta-analysis, $\mathrm{Li}$ et al. showed that $K R A S$-mutant tumours were more likely to be PD-L1-positive than were KRAS-WT tumours $(51 \% v s .36 \%$; OR $=1.69,95 \% \mathrm{CI}=1.01$ 2.84, $p=0.045$ ) (57).

Chen et al. studied the correlation between KRAS mutation and PD-L1 expression. They demonstrated that KRAS mutation in NSCLC induced up-regulation of PD-L1 by persistent activation of downstream effectors through pERK signalling. Moreover, the authors found that upregulation of PD-L1 by KRAS mutation induced apoptosis of $\mathrm{CD}^{+}$T-cells through the PD-1-PD-L1 axis and, consequently, exhaustion of T-cells, which resulted in the immune escape of NSCLC cells (58).

D'Incecco et al. described the relationship of PD-1 positivity with smoking status $(p=0.02)$ and KRAS mutation $(p=0.002)$ in patients with NSCLC (50). Davar et al. described a complete 

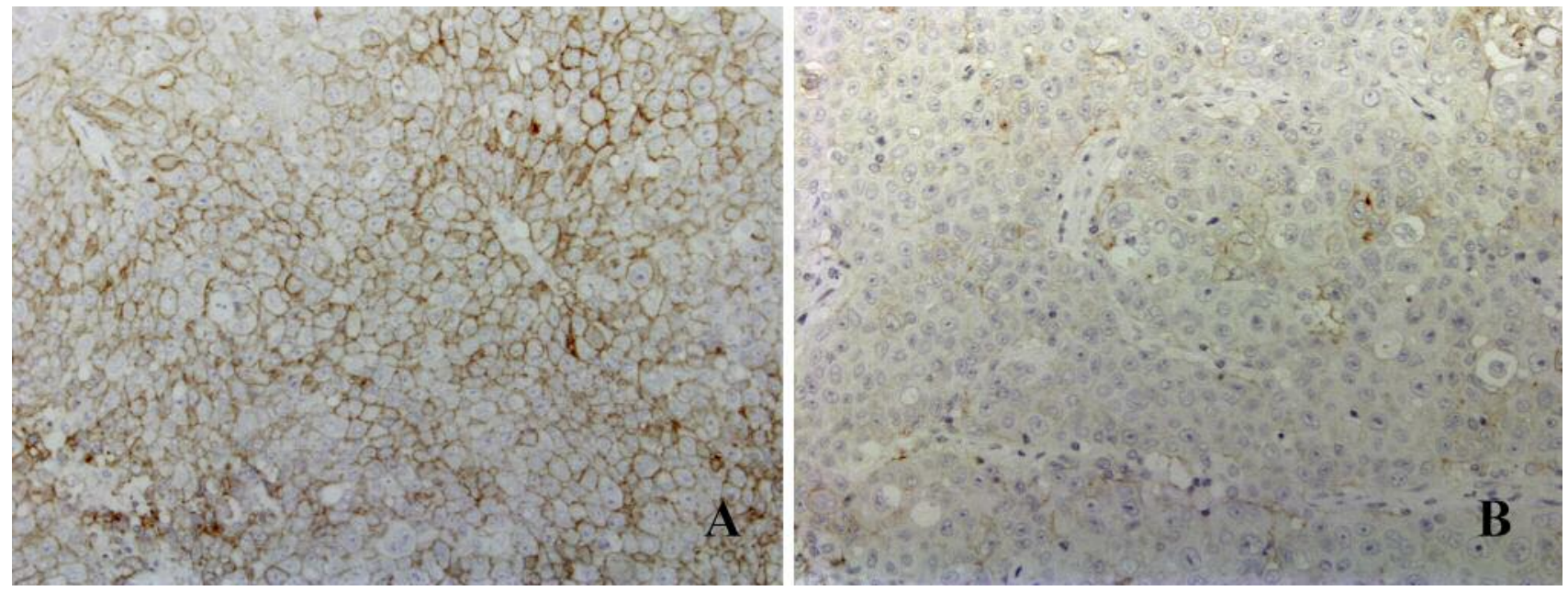

Figure 1. Programmed death ligand-1 (PD-L1) expression in non-small cell lung cancer in regard to suitability for immunotherapy. A: Increased PD-L1 expression in $>50 \%$ of the tumour cells, with a distinctive pattern of membranous positivity. B: PD-L1 expression in fewer than $2 \%$ of the tumour cells, which according to the threshold is considered negative, therefore the patient would not be eligible for immunotherapy.

response to nivolumab in a patient with advanced $K R A S$ mutant pulmonary adenocarcinoma (59). In CheckMate 057, a subgroup analysis showed that nivolumab had a greater survival benefit in patients with $K R A S$-mutant tumours than WT (52). Rizvi et al. showed that KRAS mutation was most frequent in patients with NSCLC who were smokers, with a durable clinical benefit with pembrolizumab (60).

\section{Other Drivers}

Kadara et al. revealed that PD-L1 levels were significantly elevated in TP53-mutant lung adenocarcinoma $(p=0.002)$ and reduced in PIK3CA-mutant tumours ( $\mathrm{p} \leq 0.001)(61)$. Choi $\mathrm{M}$ et al. found that $P I K 3 C A$ mutations were associated with reduced expression of tumoural PD-L1 and peritumoural PD-1 $(p<0.05)(62)$.

\section{Conclusion}

Immunotherapy with monoclonal antibodies to PD-1, such as nivolumab and pembrolizumab, significantly improved the survival of patients with metastatic NSCLC. The efficacy of these new agents varies across individual patients, hence the importance of and need for research on biomarkers that predict response to treatment $(63,64)$. IHC staining for PDL1 has been approved as a companion diagnostic tool by the US Food and Drug Administration for patients with advanced NSCLC for pembrolizumab (64) (Figure 1).

However, several studies showed that the predictive role of tumour PD-L1 expression was limited due to the variation in immunoreaction that such antibodies can show based on clinicopathological parameters such as stage of disease (early resected vs. advanced tumour), prior chemotherapy or targeted therapy (EGFR- or ALK-TKIs), prior radiotherapy, gender, mutation status of NSCLC (EGFR, ALK, KRAS), tumour differentiation, histology, and the presence of $\mathrm{CD}^{+}$TILs.

It is also well-known that intratumoural heterogeneity exists based on polyclonal evolution of the tumour that in some cases can show a strong but patchy expression of the antibody in specific areas and negative staining in others. Such variability can be limited by the use of different or limited diagnostic samples such as cytology or small biopsy or a non-adequate histopathological sampling of large tumoural masses.

The definition of the threshold in terms of the percentage of positively stained cells and the use of different assays or antibodies can also affect the determination of PD-L1 expression in cancer. Therefore, IHC using anti-PD-L1 may not represent the true PD-L1 status of the tumour but might represent only its expression under specific conditions and IHC staining may increase considerably at later time points in the disease course.

PD-L1 expression appears to be associated with EGFR mutation and EML4-ALK fusion protein in NSCLC (43-59). Pre-clinical models showed that these oncogenic alterations can promote an immunosuppressive tumour microenvironment, mediating immune escape of NSCLC. Thus, antibodies to PD1/PD-L1 may represent an optional therapy in these settings (65). Currently, the role of combination therapy of EGFRTKIs and immunotherapy is under investigation. In consideration of tumour heterogeneity and the variability of PD-L1 expression, re-biopsy and the re-evaluation of this biomarker after conventional treatments should be considered 
in patients that were not previously eligible for immunotherapy. Further prospective trials are necessary to evaluate this therapeutic approach.

\section{References}

1 Ettinger DS, Wood DE, Aisner DL et al: NCCN Clinical Practice Guidelines in Oncology Non-Small Cell Lung Cancer, v4.2017. Available at NCCN.org. Accessed March 15, 2017.

2 Mu CY, Huang JA, Chen Y, Chen C and Zhang XG: High expression of PD-L1 in lung cancer may contribute poor prognosis and tumor cells immune escape through suppressing tumour infiltrating dendritic cells maturation. Med Oncol 28: 682-688, 2011.

3 Chen YY, Wang LB, Zhu HL, Li XY, Zhu YP, Yin YL, Lü FZ, Wang ZL and Qu JM: Relationship between programmed deathligand 1 and clinicopathological characteristics in non small cell lung cancer patients. Chin Med Sci J 28: 147-15, 2013.

4 Brahmer J, Reckamp KL, Baas P, Crinò L, Eberhardt WE, Poddubskaya E, Antonia S, Pluzanski A, Vokes EE, Holgado E, Waterhouse D, Ready N, Gainor J, Arén Frontera O, Havel L, Steins M, Garassino MC, Aerts JG, Domine M, Paz-Ares L and Reck M, Baudelet C, Harbison CT, Lestini B and Spigel DR: Nivolumab versus docetaxel in advanced squamous -cell non small cell lung cancer. N Engl J Med 373: 123-135, 2015.

5 Garon EB, Rizvi NA, Hui R, Leighl N, Balmanoukian AS, Eder JP, Patnaik A, Aggarwal C, Gubens M, Horn L, Carcereny E, Ahn MJ, Felip E, Lee JS, Hellmann MD, Hamid O, Goldman JW, Soria JC, Dolled-Filhart M and Rutledge RZ, Zhang J, Lunceford JK, Rangwala R, Lubiniecki GM, Roach C, Emancipator K, Gandhi L and KEYNOTE-001 Investigators: Pembrolizumab for the treatment of non-small-cell lung cancer.N Engl J Med 372: 2018-2028, 2015.

6 Borghaei H1, Paz-Ares L, Horn L, Spigel DR, Steins M, Ready NE, Chow LQ, Vokes EE, Felip E, Holgado E, Barlesi F, Kohlhäufl M, Arrieta O, Burgio MA, Fayette J, Lena H, Poddubskaya E, Gerber DE, Gettinger SN, Rudin CM, Rizvi N, Crinò L, Blumenschein GR Jr., Antonia SJ, Dorange C, Harbison CT, Graf Finckenstein F and Brahmer JR: Nivolumab versus docetaxel in advanced non-squamous non-small-cell-lung cancer. N Engl J Med 373: 1627-1639, 2015.

7 Reck M, Rodríguez-Abreu D and Robinson AG, Hui R, Csőszi T, Fülöp A, Gottfried M, Peled N, Tafreshi A, Cuffe S, O’Brien M, Rao S, Hotta K, Leiby MA, Lubiniecki GM, Shentu Y, Rangwala R, Brahmer JR and KEYNOTE-024 Investigators: Pembrolizumab versus chemotherapy for PD-L1 positive nonsmall cell lung cancer. N Engl J Med 375: 1823-1833, 2016.

8 Malhotra J, Jabbour SK and Aisner J: Current state of immunotherapy for non-small cell lung cancer: Transl Lung Cancer Res 6: 196-211, 2017.

9 Madore J1, Vilain RE, Menzies AM, Kakavand H, Wilmott JS, Hyman J, Yearley JH, Kefford RF, Thompson JF, Long GV, Hersey P and Scolyer RA: PD-L1 expression in melanoma shows marked heterogeneity within and between patiens: implications for anti -PD.1/PD-L1 clinical trials. Pigment Cell Melanoma Res 28: 245-53, 2014.

10 Fridman WH, Zitvogel L, Sautès-Fridman C and Kroemer G: The immune contexture in cancer prognosis and treatment. Nat Rev Clin Oncol 14: 717-734, 2017.
11 Zhang P, Su DM, Liang M and Fu J: Chemopreventive agents induce programmed death-1 ligand 1 (PD-L1) surface expression in breast cancer cells and promote PD-L1 mediated T cell apoptosis. Mol Immunol 45: 147, 2008.

12 Ghebeh H, Lehe C, Barhoush E, Al-Romaih K and Tulbah A, Al-Alwan M, Hendrayani SF, Manogaran P, Alaiya A, AlTweigeri T, Aboussekhra A and Dermime S: Doxorubicin downregulates cell surface B7-H1 expression and upregulates its nuclear expression in breast cancer cells: role of B7-H1 as antiapoptotic molecule. Breast Cancer Res 12: R48, 2010.

13 Bylicki O, Paleiron N, Margery J, Guisier F, Vergnenegre A, Robinet G, Auliac JB, Gervais R and Chouaid C: Targeting the PD-1/PD-L1 immune checkpoint in EGFR-mutated or $A L K$ translocated non-small-cell lung cancer. Target Oncol 12: 563$569,2017$.

14 Reynders K, Illidge T, Siva S, Chang JY and De Ruysscher D: The abscopal effect of local radiotherapy: using immunotherapy to make a rare event clinically relevant. Cancer Treat Rev 41: 503-510, 2015.

15 Shaverdian N, Lisberg AE, Bornazyan K, Veruttipong D, Goldman JW, Formenti SC, Garon EB and Lee P: Previous radiotherapy and the clinical activity and toxicity of pembrolizumab in the treatment of non-small-cell lung cancer: a secondary analysis of the KEYNOTE-001 phase 1 trial. Lancet Oncol 18: 895-903, 2017.

16 Schreiber RD, Old LJ and Smyth MJ: Cancer immunoediting: integrating immunity's roles in cancer suppression and promotion. Science 331: 1565-1570, 2011.

17 Nurieva RI, Liu X and Dong C: Yin-Yang of co-stimulation: Crucial controls of immune tolerance and function. Immunol Rev 229: 88-100, 2009.

18 Tumeh PC, Harview CL, Yearley JH, Shintaku IP, Taylor EJ, Robert L, Chmielowski B, Spasic M, Henry G, Ciobanu V, West AN, Carmona M, Kivork C, Seja E, Cherry G, Gutierrez AJ, Grogan TR, Mateus C, Tomasic G, Glaspy JA, Emerson RO, Robins H, Pierce RH, Elashoff DA, Robert C and Ribas A: PD1 blockade induces responses by inhibiting adaptive immune resistance. Nature 515: 568-571, 2014.

19 Daud AI, Loo K, Pauli ML, Sanchez-Rodriguez R and Sandoval PM, Taravati K, Tsai K, Nosrati A, Nardo L, Alvarado MD, Algazi AP, Pampaloni MH, Lobach IV, Hwang J, Pierce RH, Gratz IK, Krummel MF and Rosenblum MD: Tumor immune profiling predicts response to anti-PD-L1 therapy in human melanoma. J Clin Invest 126: 3447-3452, 2016.

20 Erdag G, Schaefer JT, Smolkin ME, Deacon DH, Shea SM, Dengel LT, Patterson JW and Slingluff CL Jr: Immunotype and immunoistologic characteristics of tumor-infiltrating immune cells are associated with clinical outcome in metastatic melanoma. Cancer Res 72: 1070-1080, 2012.

21 Feng Z, Puri S, Moudgil T, Wood W, Hoyt CC, Wang C, Urba WJ, Curti BD, Bifulco CB and Fox BA: Multispectral imaging of formalin-fixed tissue predicts ability to generate tumor-infiltrating lymphocytes from melanoma. J Immunother cancer 3: 47, 2015.

22 McLaughlin J, Han G, Schalper KA, Carvajal-Hausdorf D and Pelekanou V, Rehman J, Velcheti V, Herbst R, LoRusso P and Rimm DL: Quantitative assessment of the heterogeneity of PDL1 expression in non-small cell lung cancer (NSCLC). JAMA Oncol 2: 46-54, 2016.

23 Hansen AR and Siu LL: PD-L1 testing in cancer: challenges in companion diagnostic development. JAMA Oncol 2: 15-16, 2016. 
24 Sacher AG and Gandhi 1: Biomarkers for the clinical use of PD1/PD-L1 inhibitors in non-small cell lung cancer: A review. JAMA Oncol 2: 1217-1222, 2016.

25 Patel S and Kurzrock R: PD-L1 expression as a predictive biomarker in cancer immunotherapy. Mol Cancer Ther 14: 847$56,2015$.

26 Bussolati $G$ and Leonardo E: Technical pitfalls potentially affecting diagnoses in immunohistochemistry. J Clin Pathol 61: 1184-1192, 2008.

27 Yang CY, Lin MW, Chang YL, Wu CT and Yang PC: Programmed cell death-ligand 1 expression in surgically resected stage 1 pulmonary adenocarcinoma and its correlation with driver mutations and clinical outcomes. Eur J Cancer 50: 1361$1369,2014$.

28 Velcheti V, Schalper KA, Carvajal DE, Anagnostou VK, Syrigos KN, Sznol M, Herbst RS, Gettinger SN, Chen L and Rimm DL: Programmed death ligand-1 expression in non small cell lung cancer. Lab Invest 94: 107-116, 2014.

29 Jiang L, Su X, Zhang T, Yin X, Zhang M, Fu H, Han H, Sun Y, Dong L, Qian J, Xu Y, Fu X, Gavine PR, Zhou Y, Tian K, Huang J, Shen D, Jiang H, Yao Y, Han B and Gu Y: PD-L1 expression and its relationship with oncogenic drivers in non-small-cell lung cancer (NSCLC). Oncotarget 8: 26845-26857, 2017.

30 Han JJ, Kim DW, Koh J, Keam B, Kim TM, Jeon YK, Lee SH, Chung DH and Heo DS: Change in PD-L1 expression after acquiring resistance to gefitinib in EGFR-mutant non-small cell lung cancer. Clin Lung Cancer 17: 263-270, 2016.

$31 \mathrm{Ma}$ W, Gilligan BM, Yuan J and Li T: Current status and perspectives in translational biomarker research for PD-1/PD-L1 immune checkpoint blockade therapy. J Hematol Oncol 9: 47, 2016.

32 Pan ZK, Ye F, Wu X, An HX and Wu JX: Clinopathological and prognostic significance of programmed cell death ligand 1 (PDL1) expression in patients with non-small cell lung cancer: A meta analysis. Thorac Dis 7: 462-470, 2015.

$33 \mathrm{Mu}$ CY, Huang JA, Chen Y, Chena $\mathrm{C}$ and Zhang XG: High expression of PD-L1 in lung cancer may contribute to poor prognosis and tumor cells immune escape through suppressing tumor-infiltrating dendritic cells maturation. Med Oncol 28: 682688,2011

34 Tsao MS, Le Teuff G, Shepherd FA, Landais C, Hainaut P, Filipits M, Pirker R, Le Chevalier T, Graziano S, Kratze R, Soria JC, Pignon JP, Seymour L and Brambilla E: PD-L1 protein expression assessed by immunohistochemistry is neither prognostic nor predictive of benefit from adjuvant chemotherapy in resected nonsmall cell lung cancer. Ann Oncol 28: 882-889, 2017.

35 Kadara H, Choi M, Zhang J, Parra ER, Rodriguez-Canales J, Gaffney SG, Zhao Z, Behrens C, Fujimoto J, Chow C, Yoo Y, Kalhor N, Moran C, Rimm D, Swisher S, Gibbons DL, Heymach J, Kaftan E, Townsend JP, Lynch TJ, Schlessinger J, Lee J, Lifton RP, Wistuba II and Herbst RS: Whole-exome sequencing and immune profiling of early-stage lung adenocarcinoma with fully annotated clinical follow up. Ann Oncol 28: 75-82, 2017

36 Sheng J, Fang W, Yu J, Chen N, Zhan J, Ma Y, Yang Y, Huang $\mathrm{Y}$, Zhao $\mathrm{H}$ and Zhang L: Expression of programmed death ligand-1 on tumor cells varies pre and post chemotherapy in non small cell lung cancer. Sci Rep 6: 23850, 2016.

37 McGranahan N, Furness AJ, Rosenthal R, Ramskov S, Lyngaa R, Saini SK, Jamal-Hanjani M and Wilson GA, Birkbak NJ,
Hiley CT, Watkins TB, Shafi S, Murugaesu N, Mitter R, Akarca AU, Linares J, Marafioti T, Henry JY, Van Allen EM, Miao D, Schilling B, Schadendorf D, Garraway LA, Makarov V, Rizvi NA, Snyder A, Hellmann MD, Merghoub T, Wolchok JD, Shukla SA, Wu CJ, Peggs KS, Chan TA, Hadrup SR, Quezada SA and Swanton C: Mutational landscape determines sensitivity to PD. 1 blockade in non-small cell lung cancer. Science 348 : 124-128, 2015.

38 McGranahan N, Furness AJ, Rosenthal R, Ramskov S, Lyngaa R, Saini SK, Jamal-Hanjani M and Wilson GA, Birkbak NJ, Hiley CT, Watkins TB, Shafi S, Murugaesu N, Mitter R, Akarca AU, Linares J, Marafioti T, Henry JY, Van Allen EM, Miao D, Schilling B, Schadendorf D, Garraway LA, Makarov V, Rizvi NA, Snyder A, Hellmann MD, Merghoub T, Wolchok JD, Shukla SA, Wu CJ, Peggs KS, Chan TA, Hadrup SR, Quezada SA and Swanton C: Clonal neoantigens elicit T-cell immunoreactivity and sensitivity to immune checkpoint blockade. Science 351 : 1463-1469, 2016.

39 Jiang L, Su X, Zhang T, Yin X, Zhang M, Fu H, Han H, Sun Y, Dong L, Qian J, Xu Y, Fu X, Gavine PR, Zhou Y, Tian K, Huang J, Shen D, Jiang H, Yao Y, Han B and Gu Y: PD-L1 expression and its relationship with oncogenic drivers in non-small cell lung cancer (NSCLC). Oncotarget 8: 26845-26857, 2017.

40 Azuma K, Ota K, Kawahara A, Hattori S, Iwama E, Harada T, Matsumoto K, Takayama K, Takamori S, Kage M, Hoshino T, Nakanishi Y and Okamoto I: Association of PD-L1 overexpression with activating $E G F R$ mutations in surgically resected non small cell lung cancer. Ann Oncol 25: 1935-1940, 2014.

41 D’Incecco A, Andreozzi M, Ludovini V, Rossi E, Capodanno A, Landi L, Tibaldi C, Minuti G, Salvini J, Coppi E, Chella A, Fontanini G, Filice ME, Tornillo L, Incensati RM, Sani S, Crinò L, Terracciano L and Cappuzzo F: PD-1 and PD-L1 expression in molecularly selected non-small cell lung cancer patients. B J Cancer 112: 95-102, 2015.

42 Akbay EA, Koyama S, Carretero J, Altabef A, Tchaicha JH, Christensen CL, Mikse OR, Cherniack AD, Beauchamp EM, Pugh TJ, Wilkerson MD, Fecci PE, Butaney M, Reibel JB, Soucheray M, Cohoon TJ, Janne PA, Meyerson M, Hayes DN, Shapiro GI, Shimamura T, Sholl LM, Rodig SJ, Freeman GJ, Hammerman PS, Dranoff G and Wong KK: Activation of the PD-1 pathway contributes to immune escape in EGFR-driven lung tumors. Cancer Discov 3: 1355-1363, 2013.

43 Chen N, Fang W, Zhan J, Hong S, Tang Y, Kang S, Zhang Y, He $X$, Zhou T, Qin T, Huang Y, Yi X and Zhang L: Up-regulation of PD-L1 by EGFR activation mediates the immuno-escape in EGFR-driven NSCLC. Implication for optional immune targeted therapy for NSCLC patients with EGFR mutation. J Thorac Oncol 10: 910-923, 2015.

44 Zhang N, Zeng Y, Du W, Zhu J, Shen D, Liu Z and Huang JA: The EGFR pathway is involved in the regulation of PD-L1 expression via the IL-6/JAK/STAT3 signaling pathway in EGFR-mutated non-small cell lung cancer. Int J Oncol 49: 1360$1368,2016$.

45 Okita R, Maeda A, Shimizu K, Nojima Y, Saisho S and Nakata M: PD-L1 overexpression is partially regulated by EGFR/HER2 signaling and associated with poor prognosis in patients with non-small-cell lung cancer. Cancer Immunol Immunother 66: 865-876, 2017.

46 Tang Y, Fang W, Zhang Y, Hong S, Kang S, Yan Y, Chen N, Zhan J, He X, Qin T, Li G, Tang W, Peng P and Zhang L: The 
association between PD-L1 and EGFR status and the prognostic value of PD-L1 in advanced non-small cell lung cancer patients treated with EGFR-TKIs. Oncotarget 6: 14209-14219, 2015.

47 Gainor JF, Shaw AT, Sequist LV, Fu X, Azzoli CG, Piotrowska Z, Huynh TG, Zhao L, Fulton L, Schultz KR, Howe E, Farago AF, Sullivan RJ, Stone JR, Digumarthy S, Moran T, Hata AN, Yagi Y, Yeap BY, Engelman JA and Mino-Kenudson M: EGFR mutations and $A L K$ rearrangements are associated with low response rates to PD-1 pathway blockade in non-small cell lung cancer: A retrospective analysis. Clin Cancer Res 22: 4585-4593, 2016.

48 D'Incecco A, Andreozzi M, Ludovini V, Rossi E, Capodanno A, Landi L, Tibaldi C, Minuti G, Salvini J, Coppi E, Chella A, Fontanini G, Filice ME, Tornillo L, Incensati RM, Sani S, Crinò L, Terracciano L and Cappuzzo F: PD-1 and PD-L1 expression in molecularly selected non-small-cell lung cancer patients. $\mathrm{Br}$ J Cancer 112: 95-102, 2015.

49 Haratani K, Hayashi H, Tanaka T, Kaneda H, Togashi Y, Sakai K, Hayashi K, Tomida S, Chiba Y, Yonesaka K, Nonagase Y, Takahama T, Tanizaki J, Tanaka K, Yoshida T, Tanimura K, Takeda M, Yoshioka H, Ishida T, Mitsudomi T, Nishio K and Nakagawa K: Tumor immune microenvironment and nivolumab efficacy in EGFR mutation-positive non-small-cell lung cancer based on T790M status after disease progression during EGFRTKI treatment. Ann Oncol 28: 1532-1539, 2017.

50 Herbst RS, Baas P, Kim DW, Felip E, Gracia JLP, Han JY, Molina J, Kim JH, Arvis CD, Ahn MJ, Majem M, Fidler MJ, de Castro G, Garrido M, Lubiniecki GM, Shentu Y, Im E, DolledFilhart $\mathrm{M}$ and Garon EB: Pembrolizumab versus docetaxel for previously treated, PD-L1 positive, advanced non-small-cell lung cancer (KEYNOTE-010): A randomised controlled trial. Lancet 387: 1540-1550, 2016.

51 Ahn MJ, Sun JM, Lee SH, Ahn JS and Park K: EGFR TKI combination with immunotherapy in non-small cell lung cancer Expert Opin Drug Saf 16: 465-469, 2017.

52 Gettinger S, Rizvi N, Chow LQ, Borghaei H, Brahmer JR, Juergens R, Shepherd AF, Laurie SA, Gerber DE, Goldman J, Shen Y, Harbison C, Chen A and Antonia SJ: Nivolumab (anti-PD-1; BMS 936558, ONO-4538) in combination with platinum based doublt chemotherapy (Pt_DC) or elotinib in advanced non-small cell lung cancer (NSCLC). Ann Oncol 25: iv361-iv372, 2014.

53 Ahn MJ, Yang J, Yu H, Saka H, Ramalingam S, Goto K, Kim SW, Yang L, Walding A and Oxnard GR: 136O: Osimertinib combined with durvalumab in EGFR-mutant non-small cell lung cancer: results from the TATTON phase Ib trial. J Thorac Oncol 11: S115, 2016.

54 Grosso J, Horak CE, Inzunza D, Cardona DM, Simon JS, Gupta AK, Sankar V, Park JS, Kollia G, Taube JM, Anders M, Jure Kunkel M, Novotny JM, Taylor CR, Zhang X, Phillips T, Simmons $\mathrm{P}$ and Gogswell J: Association of tumor PD-L1 expression and immune biomarkers with clinical activity in patients (pts) with advanced solid tumors treated with nivolumab (anti-PD-1; BMS-936558; ONO-4538). J Clin Oncol 31(suppl 15): 3016-3016, 2013.

55 Hong S, Chen N, Fang W, Zhan J, Liu Q, Kang S, He X, Liu L, Zhou T, Huang J, Chen Y, Qin T, Zhang Y, Ma Y, Yang Y, Zhao Y, Huang Y and Zhang L: Up-regulation of PD-L1 by EML4ALK fusion protein mediates the immune escape in ALKpositive NSCLC: Implication for optional anti-PD-1/PD-L1 immune therapy for ALK-TKIs sensitive and resistant NSCLC patients. Oncoimmunology 5: e1094598, 2016.
56 Ota K, Azuma K, Kawahara A, Hattori S, Iwama E, Tanizaki J, Harada T, Matsumoto K, Takayama K, Takamori S, Kage M, Hoshino T, Nakanishi Y and Okamoto I: Induction of PD-L1 expression by the EML4-ALK oncoprotein and dowstreaming signaling pathways in non-small cell Lung cancer. Clin Cancer Res 21(17): 4014-4021, 2015.

$57 \mathrm{Li}$ D, Zhu X, Wang H and Li N: Association between PD-L1 expression and driven gene status in NSCLC: A meta-analysis. Eur J Surg Oncol 43: 1372-1379, 2017.

58 Chen N, Fang W, Lin Z, Peng P, Wang J, Zhan J, Hong S, Huang J, Liu L, Sheng J, Zhou T, Chen Y, Zhang $\mathrm{H}$ and Zhang L: KRAS mutation-induced upregulation of PD-L1 mediates immune escape in human lung adenocarcinoma. Cancer Immunol Immunother 66: 1175-1187, 2017.

59 Davar D, Socinski MA. Dacic S and Burns TF: Near complete response after single dose of nivolumab in patient with advanced heavily pre-treated KRAS-mutant pulmonary adenocarcinoma. Exp Hematol Oncol 4: 34, 2015.

60 Rizvi NA, Hellmann MD, Snyder A, Kvistborg P, Makarov V, Havel JJ, Lee W, Yuan J, Wong P, Ho TS, Miller ML, Rekhtman N, Moreira AL, Ibrahim F, Bruggeman C, Gasmi B, Zappasodi R, Maeda Y, Sander C, Garon EB, Merghoub T, Wolchok JD, Schumacher TN and Chan TA: Cancer immunology. Mutational landscape determines sensitivity to PD-1 blockade in non-small cell lung cancer. Science 348: 124-128, 2015.

61 Kadara H, Choi M, Zhang J, Parra ER, Rodriguez-Canales J, Gaffney SG, Zhao Z, Behrens C, Fujimoto J, Chow C, Yoo Y, Kalhor N, Moran C, Rimm D, Swisher S, Gibbons DL, Heymach J, Kaftan E, Townsend JP, Lynch TJ, Schlessinger J, Lee J, Lifton RP, Wistuba II and Herbst RS: Whole-exome sequencing and immune profiling of early-stage lung adenocarcinoma with fully annotated clinical follow-up. Ann Oncol 28: 75-82, 2017.

62 Choi M, Kadara H, Zhang J, Parra ER, Rodriguez-Canales J, Gaffney SG, Zhao Z, Behrens C, Fujimoto J, Chow C, Kim K, Kalhor N, Moran C, Rimm D, Swisher S, Gibbons DL, Heymach J, Kaftan E, Townsend JP, Lynch TJ, Schlessinger J, Lee J, Lifton RP, Herbst RS and Wistuba II: Mutation profiles in early-stage lung squamous cell carcinoma with clinical follow-up and correlation with markers of immune function. Ann Oncol 28: 83-89, 2017.

$63 \mathrm{Ma}$ W, Gilligan BM, Yuan J and Li T: Current status and perspectives in translational biomarker research for PD-1/PD-L1 immune checkpoint blockade therapy. J Hematol Oncol 9: 47, 2016.

64 Shukuya T and Carbone D: Predictive markers for the efficacy of anti-PD-1/PD-L1 antibodies in lung cancer. J Thorac Oncol 11: 976-988, 2016.

65 Nishino M, Ramaiya NH, Hatabu H and Hodi S: Monitoring immune-checkpoint blockade: response evaluation and biomarker development. Nat Rev Clin Oncol 14: 655-668, 2017.

Received March 11, 2018

Revised May 19, 2018

Accepted May 23, 2018 